\title{
STUDENTS' PERCEPTIONS TOWARDS EXTENSIVE READING IN EFL CONTEXTS
}

\author{
Rini Lindawati \\ Universitas Islam Majapahit, Mojokerto, Indonesia \\ rinilindawati@unim.ac.id \\ Submitted : 01/August/2021 \\ Accepted : 08/August/2021 \\ Publication: 08/August/2021
}

\begin{abstract}
Most university students are struggling in learning English as Foreign Language. The utilization of an extensive reading strategy will potentially promote more striking influential impacts on EFL learners' target language proficiency. The students' perceptions influence the success of teaching and learning English. The research aimed to know the students' perception of Extensive Reading in EFL contexts. The researcher used the Qualitative Research method. This study was conducted in Universitas Islam Majapahit. The researcher selected twelve senior students of the English language education department who have already received the extensive reading subject in their previous semesters. The researcher collected the data through semi-structured interviews. The data were then analyzed by following Miles and Huberman's (1994) framework. The results showed that the students had positive perceptions toward Extensive Reading practices. They considered if Extensive Reading is a reading activity for pleasure and information search where they can read material without any restraint. Besides, Extensive Reading also contributed to developing their comprehension and English skills such as listening, speaking, reading, writing, vocabulary mastery, and grammar. Moreover, Extensive Reading enabled them to enjoy the learning experience.
\end{abstract}

Keywords - EFL Learners, Extensive Reading, Reading Activities.

\section{Introduction}

English in Indonesia is learned as a foreign language which makes the students, mainly English department students, read a lot of English text to improve their English skills, such as writing, speaking, listening, and reading. Therefore, reading for EFL students will become a habit if they practice it as the main course of their learning activity. Iftanti (2015) mentioned that good reading habits for EFL students appoint to reading various types of English reading materials that regularly and intentionally established becomes EFL students' daily activity.

Meanwhile, in Indonesia, the lack of reading interest is still high enough among EFL students. As a result, it could detain their learning process and understanding of the material. Cain, Oakhill, \& Bryant (2004) stated that poor readers are poor at making inferences and find difficulties understanding the text. Besides, the result of the research (Andreas, 2018) has shown that Indonesian EFL students' reading interest was on level 1, which indicated that they have a low level on it. Having the motivation to read is essential for students. Similar to Guthrie, Wigfield, \& Vonsecker (2000), reading motivation is the person's goals, values, and beliefs connected to the reading's topics, processes, and outcome.

According to Dwyer, Hogan, \& Stewart (2014), EFL students at the university level usually receive reading courses that force them to read several materials to improve their critical thinking, which increases the chances to produce a logical conclusion to understand the content itself. Thus, students' reading habits encourage their understanding. Students who enjoy reading 
outside the classroom for pleasure or reading to look for general information perform the Extensive Reading activity.

One of the efficient reading strategies language teachers should use on their daily class basis is Extensive Reading. The utilization of an extensive reading strategy will potentially promote more striking influential impacts on EFL learners' target language proficiency, learning moods, behaviors, and engagement. Through Extensive Reading, EFL learners will experience a higher degree of L2 reading learning enjoyment, free-chosen reading texts attracting their reading interest most, and the feasible reading speed as well as accuracy suitably matched with existing learners' reading proficiency.

In EFL context, Extensive Reading (ER) is an approach for teaching reading whose goal is to get students reading in the English language and enjoying it (Day, Bassett, Bowler, \& Parminter, 2011). In Short, Grabe, as cited in (Wilkinson, 2012) discusses some of the benefits of Extensive Reading: building vocabulary and structural awareness, enhancing background knowledge, developing automaticity, improving comprehension skills, and promoting confidence and motivation. . The students themselves decide the topic selected. The principles of Extensive Reading for EFL students have been compiled by Day \& Bamford (2002) as follows:

1. The reading material is easy.

2. A variety of reading material on a wide range of topics must be available.

3. Learners choose what they want to read.

4. Learners read as much as possible.

5. The purpose of reading is usually related to pleasure, information, and a general understanding.

6. Reading is its reward.

7. Reading speed is usually faster rather than slower.

8. Reading is individual and silent.

9. Teachers orient and guide their students.

10. The teacher is a role model of a reader.

Based on the ten principles above, the researcher could conclude that extensive reading is an activity that will not depress the students.

Teaching English plays a vital role in position and success as a foreign language. The students' perceptions influence the success of teaching and learning English. If the teachers know the students' perceptions of teaching and learning English, they can decide the appropriate teaching media. The students will be able to learn the materials if they understand their perceptions. Understanding their perceptions will know what they need and what teaching media is helpful for them. Perception is the identification, interpretation, and presentation of specific information. According to (Démuth, 2013), perception is the process of recognizing (being aware of), organizing (gathering and storing), and interpreting (binding to knowledge) sensory information. Besides that, perception is a cognitive process that everyone does to choose, organizing, analyzing, listening to the news.

The previous research conducted by Chen (2013) showed how extensive reading via ebook on EFL students' reading attitude. The result of the study showed that the use of e-book in extensive reading practices could facilitate Taiwanese EFL students' tertiary level of English reading attitude, reading comprehension, and vocabulary growth. Another research conducted by Mikami (2017) about Extensive Reading among EFL students in Japan mentioned that the students lack experience in the Extensive Reading activities in the classroom. Six years of English education also imply that they have been received before entering university did not provide enough opportunity to read extensively in English or build steady reading habits toward English context.

On the other hand, Lien (2017) research focused only on the self-selected materials by the students who wanted to implement the Extensive Reading activity. The result of the study reported that the students preferred to read authentic books than graded books although it was more challenging. They thought graded books could not make adult learners at a high intermediate level more interested and motivated. However, according to the research about 
Extensive Reading mentioned above, there is still a lack of information about student's perception toward extensive reading. Furthermore, there is still much research about Extensive Reading and its benefit in one English skill only.

The gaps encouraged the researcher to study students' perceptions towards Extensive Reading in EFL contexts. To fulfill this research objectivity, one formulation of the problem in this study is: what are the students' perceptions toward the use of Extensive Reading in EFL Context?

\section{Research Method}

This research aims to know the students' perceptions towards Extensive Reading in EFL Contexts. It is relevant to the characteristics of the qualitative research approach that explores personal or individual perspectives in identifying their surroundings and occurrences (Dost \& Hafshejani, 2017). The data will analyze by using several types, namely organizing and familiarizing, coding and reducing, and interpreting and representing (Ary, Jacobs, and Sorensen, 2010). The first thing which the researcher did is introducing. Here, the researcher should be familiar with the data, such as reading the students' interview answers and transcript, rereading, and listening to the audio recording repeatedly. The researcher read all of the data to input into a form ready for analysis. The transcription must be made all of the data. The researcher should transcribe the words directly to avoid bias or interpretation, which may happen on summarizing. After familiarizing myself, the next step is coding. It is the step that was developing concepts from the raw data. In this step, the researcher read and reread all the data from students' answers and separate them by seeing particular meanings such as ways of thinking, habits patterns, and events that seem to appear regularly and essential. The last researcher did interpreting and representing the data.

The subjects of this research were the senior students of the English education study program in Universitas Islam Majapahit, Mojokerto. The researcher chose twelve students who have received the extensive reading subject in their previous semester. This study used a semi-structured interview to collect information from the students. To get the data, the researcher executed an interview with the participants by phone and recorded it. Creswell (2012) defines an interview as an appropriate instrument to get deeper information in qualitative research. Semi-structured interviews were used to collect the data about students' perception toward the use of Extensive Reading in EFL Contexts. This type requires the researcher to design or arrange guidelines from the topic (Moleong, 2005). This guideline acts as the main focus of the interview. This interview used open-ended questions.

\section{Results and Discussion}

\section{Students' Perception Towards Extensive Reading in EFL Context}

Table 1. Students' Perception of Extensive Reading based on the indicator (getting information

\begin{tabular}{|lc|}
\hline \multicolumn{1}{|c|}{ Items for getting information } & Percentage \\
Getting new information & $75 \%$ \\
Getting new knowledge & $75 \%$ \\
Getting new vocabularies & $100 \%$ \\
Improve reading comprehension & $58 \%$ \\
Reading fluency & $100 \%$ \\
\hline
\end{tabular}

All the students agreed that they get some new information from extensive reading activities from the table above. 9 out of 12 students mentioned that they also get a new piece of knowledge, such as the author's point of view, cultures in another country, and the types of texts. One of the students mentioned that: 
"From extensive reading, I knew about the culture in other countries."

All of the students agreed that Extensive Reading as a strategy in learning English helps students gain more vocabulary. Ariana (2016) revealed that nearly all Indonesian University EFL learners underwent more significant vocabulary knowledge improvements in Extensive Reading activities. One of the students mentioned that:

"Extensive Reading helped me a lot to gain more vocabulary. I guess my vocabularies have been plentiful after joining Extensive Reading class".

This statement above may be due to the mutual correlations between their actual vocabulary knowledge and the immediate nature of incidental vocabulary learning induced by extensive reading strategy potentially, broadening their word amounts swiftly in an enjoyable manner. Similar to Yanto, Saefullah, \& Kwary (2020) unfolding that most university EFL learners had successfully improved their target language competencies, including their vocabulary knowledge, after being constantly supervised by their teachers in selecting the most appropriate L2 reading texts that suit them most.

Furthermore, the results showed that 7 out of 12 students said that Extensive Reading could improve students' reading comprehension, a student said:

"I understand about the context of the text better than before I join the Extensive Reading Class".

The statement above is in line with Rankin (2005) revealed that the more students interact with text, their ability to understand the contents of the text will increase. Moreover, the results showed that most students believed that Extensive Reading enabled them to enjoy learning experiences. Nation (2009) claims the students can find enjoyment and broad knowledge in reading. The previous statement is in line with Umam (2013) stated that the students should continually extend the further implementations of Extensive Reading strategies outside of L2 classroom contexts to enable learners to experience more enjoyable second language reading learning experiences, erect more robust self-confidence, and improve their target language proficiency into the fullest potentials.

Table 2. Students' Perception of Extensive Reading based on the indicator (getting pleasure)

\begin{tabular}{|lc|}
\hline \multicolumn{1}{|c|}{ Items of getting pleasure } & Percentage \\
Read the texts/ materials & $75 \%$ \\
Pleasure to read & $83 \%$ \\
Motivate to read a lot & $75 \%$ \\
\hline
\end{tabular}

The results showed that 9 out of 12 students enjoyed reading when joining the Extensive Reading class because they could choose the texts or the materials based on their interests. Because they can choose their text in Extensive Reading, it can help the students motivated to read more (Hofer, 2011). One of the students mentioned that:

"I feel happier to read certain topics based on my interest."

Moreover, the finding indicates that all of the students agreed that Extensive Reading helps the students to read more fluently. To attain this primary objective, language teachers need to employ two beneficial strategies to preserve students' reading fluency and interests as proposed by Nation (2002), namely; (a) practicing reading faster is believed to improve the amounts of reading done by students and enable them to obtain interests toward what they have read; (b) the students are allowed to avail dictionary with the rules, it does not interrupt their reading processes. There are two ways to avoid disruptions in Extensive Reading, like taking notes of unknown words on cards 
and interpreting the meanings of new words after reading.

This research reports that the students have positive perceptions toward Extensive Reading in EFL contexts. The result supports the previous research that explained that Extensive Reading boosts students' interest in reading and improves reading skills (Gabriella \& Diptoadi, 2019). We can see that $75 \%$ of students are motivated to read extensively, and 58\% can improve their reading comprehension. Even though several participants said that Extensive Reading improves their reading comprehension, one noted that Extensive Reading does not impact their understanding of reading texts.

\section{Conclusion}

The study investigated the students' perception of Extensive Reading in EFL Contexts. The participants of this research were the students who attended the Extensive Reading class in one of the universities in Indonesia. The results showed that all the students agreed that they get some new information from extensive reading activities. As we know that Extensive Reading is an activity to read some text extensively to get information and pleasure (Day \& Bamford, 1998). Extensive Reading as a strategy in learning English helps the students to gain more vocabulary. Besides, the results showed that 7 out of 12 students said that Extensive Reading can improve students' reading comprehension. The data indicated that students believed that Extensive Reading enabled them to enjoy reading extensively. The finding suggests that all of the students agreed that Extensive Reading helps the students to read more fluently. The result showed that the students had positive perceptions. It is intended that Extensive Reading was considered valuable and meaningful. Students also experience more active improvement in their reading comprehension.

\section{References}

Al-Homoud, F., \& Schmitt, N. (2009). Extensive reading in a challenging environment: A comparison of extensive and intensive reading approaches in Saudi Arabia. Language Teaching Research, 13(4), 383-401. https://doi.org/10.1177/1362168809341508

Andreas, S. (2018). PISA 2018 insights and interpretations. OECD Publishing, 64. Retrieved from https://www.oecd.org/pisa/PISA 2018 Insights and Interpretations Final PDF.pdf

Ariana, A. (2016). Incidental Vocabulary Learning through Extensive Reading (A Study of Students in Muhammadiyah University of Makassar) (Doctoral dissertation, Pascasarjana).

Ary Donald, Jacobs Cheser, Irvine Sorensen, Walker David. (2018). Introduction to Research in Education. Cengage.

Cain, K., Oakhill, J., \& Bryant, P. (2004). Children's Reading Comprehension Ability: Concurrent Prediction by Working Memory, Verbal Ability, and Component Skills. Journal of Educational Psychology, 96(1), 31-42. https://doi.org/10.1037/00220663.96.1.31

Chen, C. N., Chen, S. C., Chen, S. H. E., \& Wey, S. C. (2013). The effects of extensive reading via e-books on tertiary level EFL students' reading attitude, reading comprehension, and vocabulary. Turkish Online Journal of Educational Technology, 12(2), 303-312.

Creswell, J. W. (2012). Planning, Conducting, and Evaluating Quantitative and Qualitative Research. Boston: Pearson Education, Inc.

Day, R. R., \& Bamford, J. (1998). Extensive reading in the second language classroom. Cambridge: Cambridge University Press.

Day \& Bamford. (2002). Top Ten Principles for Teaching Extensive Reading1. Reading in a Foreign Language, 14(2), 136-141.

Day, R. (2015). Extending Extensive reading. Reading in a Foreign Language.

Démuth, A. (2013). Perception Theories.

Dost, E. N., \& Hafshejani, N. K. (2017). The Impact of Teachers' Personality on Senior High School EFL Learners' General English Achievement. International Journal of English Literature and Social Sciences (IJELS).

Gabriella., \& Diptoadi, V.L. (2019). Students' perception of extensive reading activity through 
IJEAL (International Journal of English Education and Applied Linguistic)

Volume : 1 | Number 2 | August 2021 | E-ISSN : 2787-9482 | DOI: doi.org/ijeal.v1n1.1044

reading log. Magister Scientiae, 46.

Guthrie, J. T., Wigfield, A., \& Vonsecker, C. (2000). Motivation in reading. Journal of Educational Psychology, 92(2), 331-341. Retrieved from http://bu.umc.edu.dz/theses/anglais/GRI1048.PDF

Hofer, B. (2011). Motivation in the College Classroom. (Svinicki, M. \& McKeachie, W. J., Ed.) McKeachie's Teaching Tips. Belmont: Wadsworth.

Iftanti, E. (2015). What makes EFL students establish good reading habits in English, 3(5), 365374.

Lien, H. (2017). EFL College Learners ' Perceptions of Self-Selected Materials for Extensive Reading. The English Teacher, XXXIX(2002), 194-204. Retrieved from http://journals.melta.org.my/index.php/tet/article/view /279

Mikami, A. (2017). Students' Attitudes Toward Extensive Reading in the Japanese EFL Context. TESOL Journal, 8(2), 471-488. https://doi.org/10.1002/tesj.283

Moleong, Lexy. (2005). Metodologi Penelitian Kualitatif. Bandung: PT Remaja Rosdakarya.

Nation (2002). Managing Vocabulary Learning. Singapore: SEAMEO Regional Language Centre.

Nation, I. S. P. (2009). Language Curriculum Design. New York: Routledge.

Umam, C. (2013). Extensive Reading: What, Why, and How? Al Hikmah: Jurnal Studi Keislaman, 3(1), 25-36.

Wilkinson, D. (2012). A Data-Driven Approach to Increasing Student Motivation in the Reading Classroom. Language Education in Asia, 3.

Yanto, E. S., Saefullah, H., \& Kwary, D. A. (2020). Implementing a Literary Text Extensive Reading Program through Learning Logs. The Qualitative Report, 25(5), 1393-14 
